\title{
MODEL PENINGKATAN MINAT \\ MASYARAKAT TERHADAP MADRASAH \\ IBTIDIYAH DI JAWA TENGAH
}

\author{
$\rightarrow$ SDS \\ Oleh: Aji Sofanudin \\ Balitbang Kemenag Jawa Tengah
}

\begin{abstract}
Abstrak
Penelitian ini bertujuan untuk mengetahui (1) Bagaimana minat masyarakat untuk menyekolahkan anak mereka pada MI Ma'arif Grabag 1 Magelang, (2) Bagaimana pengelolaan MI Ma'arif Grabag 1 Magelang untuk memenuhi kebutuhan masyarakat menyekolah-kan anak mereka, serta (3) Bagaimana model peningkatan minat masyarakat menyekolahkan anak mereka pada MI Ma'arif Grabag 1 Magelang, adapun hasilnya adalah:

Pertama, minat masyarakat untuk menyekolahkan anak mereka pada MI Ma'arif Grabag 1 Magelang tergolong tinggi. Hal ini ditunjukkan dengan banyaknya orang tua wali yang ikut mendaftarkan putera-puterinya ke madrasah tersebut. Kedua, pengelolaan MI Ma'arif Grabag 1 Magelang meliputi program unggulan dan pem-biasaan yang berlaku di MI Ma'arif Grabag 1. Ketiga, model peningkatan minat masyarakat menyekolahkan anak mereka pada MI Ma'arif Grabag 1 Magelang adalah dengan memiliki programprogram unggulan, membiasakan akhlak mulia, alumni banyak diterima di lembaga favorit, memiliki prestasi akademik dan prestasi non akademik yang unggul serta menjalin kerja sama yang intens dengan berbagai pihak.
\end{abstract}

Kata Kunci: Minat Masyarakat, MI Grabag 1 Magelang, Program Unggulan 


\section{A. Pendahuluan}

Minat masyarakat untuk menyekolahkan anak mereka ke madrasah disinyalir rendah. Hal ini terungkap dari hasil penelitian Zainal Achmad $^{1}$ (2007) yang menunjukkan bahwa secara nasional terjadi penurunan Angka Partisipasi Kasar (APK) Madrasah Ibtidai-yah dari tahun 2003 ke 2006, padahal di lain pihak APK SD dan MI mengalami kenaikan. Ini mengindikasikan adanya penurunan minat orang tua untuk mempercayakan pendidikan anaknya ke madrasah. Kenaikan APK pada MTs selama periode tahun 2003-2006 justru mengindikasikan lain hal mengingat asal sekolah siswa baru yang mendaftar ke MTs mencapai lebih dari 70 persen berasal dari sekolah SDN dan SD swasta. Kondisi ini bisa jadi karena daya tampung SMPN maupun swasta terbatas, sehingga lulusan SD banyak yang melanjutkan sekolahnya ke Madrasah Tsanawiyah.

Berdasarkan rasio jumlah murid dengan jumlah kelas dan sekolah di mana jumlah murid per kelas atau persekolah dari madrasah umummnya lebih rendah dari total Nasional masingmasing menurut jenjang pendidikannya. Hal ini menunjukan masih rendahnya daya tampung madrasah. Minimnya siswa bisa ditingkatkan lagi dengan meningkatkan mutu pendidikan madrasah sehingga minat untuk bersekolah di madrasah makin besar pula.

Trend penurunan minat terhadap madrasah ini tidak terjadi pada semua madrasah. MIN, MTsN, dan MAN di Malang dikenal sebagai madrasah unggul yang banyak diminati masyarakat. ${ }^{2}$ Di Jawa Tengah ada beberapa MI dan MTs yang unggul yang menyeleksi dan menolak murid di antaranya MTs Negeri 1 Semarang, MIN Bawu, MIN Jetis. ${ }^{3}$ Namun, secara umum ada penurunan minat masyarakat terhadap madrasah terutama pada madrasah-madrasah swasta.

Selain itu, madrasah juga mengidap persoalan utama yang pada umumnya kalah bersaing dengan sekolah umum untuk mempere-

\footnotetext{
${ }^{1}$ Ir. Zainal Achmad, MSi. Analisis Tingkat Partisipasi Pendidikan Siswa Madrasah, www.pendis.kemenag.go.id diakses tanggal

${ }^{2}$ Lihat misalnya Penelitian M Mudis Taruna, Pelaksanaan KTSP pada Madrasah Tsanawiyah Negeri di Kalimantan Selatan, Jawa Timur, dan DIY (Studi pada MTsN Malang 1 Kota Malang Propinsi Jawa Timur. Semarang: Balai Penelitian dan Pengembangan Agama Semarang, 2009.
}

${ }^{3}$ Catatan Dr Nur Abadi, MPd dalam Diskusi di Balai Litbang Agama Semarang 
butkan calon siswa berprestasi. Siswa berprestasi umumnya lebih memilih sekolah umum daripada madrasah karena mereka beranggapan bahwa sekolah umum lebih menjanjikan harapan bahwa prestasi mereka akan lebih baik di sana. Madrasah dianggap kalah mutu jika dibandingkan dengan sekolah umum. Siswa madrasah juga sering merasa rendah diri jika berhadapan dengan siswa sekolah umum yang setara dengan sekolahnya.

Pengalaman Imam Suprayogo, menyebutkan ${ }^{4}$

Sudah sekian lama saya mengikuti perbincangan tentang madrasah. Dalam perbincangan itu kesimpulan yang selalu dimunculkan adalah bahwa madrasah selalu tertinggal bilamana dibandingkan dengan sekolah umum. Prestasi hasil belajar para siswanya rendah, lembaga pendidikan Islam ini dikelola dengan manajemen seadanya, gurunya kurang berkualitas, dan gajinya pun rendah. Begitu pula sarana dan prasarana pendidikan tersedia apa adanya.

Penelitian dari Tim Peneliti STAIN Salatiga (2006) tentang "Fenomena Madrasah Bubar dan Islamic Full Day School" (Studi Atas Persepsi dan Aspirasi Masyarakat Muslim Kota Surakarta dan Sekitarnya terhadap MI dan SDIT) menunjukkan banyak MI yang mengalami penurunan bahkan bubar dan tergantikan oleh SDIT. 5

Madrasah mengalami penurunan bahkan bubar dan terge-ser oleh sekolah-sekolah baru disebabkan: 1) Kinerja guru rendah, kurang profesional; 2) Kepemimpinan Kepala MI; 3) Lokasi Madrasah kurang strategis, berdekatan dengan SD Inpres; 4) Adanya guru-guru yang bermasalah.

Padahal, Undang-undang RI No 20 tahun 2003 tentang Sistem Pendidikan Nasional menyebutkan bahwa Madrasah merupakan bagian yang tidak terpisahkan dari sistem pendidikan formal di Indonesia sehingga peran Madrasah (Ibtidaiyah, Tsanawiyah dan Aliyah) tidaklah kecil terhadap pembangunan pendidikan dasar dan menengah di Indonesia, yang antara lain akan dapat dilihat dari tingkat partisipasi pendidikannya, tingkat drop-out dan berbagai indikator

\footnotetext{
${ }^{4}$ Prof Dr H Imam Suprayogo adalah Rektor UIN Malang dalam bukunya Quo Vadis Madrasah; Gagasan, Aksi, dan Solusi Pembangunan Madrasah, hlm 6

$5 \mathrm{http} / / /$ balitbangdiklat.kemenag.go.id/index.php?option=com_content\&view=artic le\&id=286:fenomena-madrasah-bubar-dan-islamic- full-day-school, accesed 21 Maret 2012
} 
lainnya pada tingkat pendidikan dasar dan menengah di Indonesia. Dengan diberlakukannya undang-undang Nomor 20 Tahun 2003 tentang sistem pendidikan nasional, paradigma madrasah dan pendidikan keagamaan pun mengalami perubahan. Sejak saat itu madrasah merupakan jenis pendidikan umum, madrasah telah menjadi bagian dari sistem pendidikan nasional.

Madrasah adalah tema besar dengan muatan sarat topik permasalahan. Berbagai upaya peningkatan kualitas madrasah baik dari segi kelemahan, sumber daya manusia, maupun kurikulum telah banyak dilakukan. Secara legal-formal, pencitraan madrasah sebagai lembaga pendidikan "kelas dua", sebenarnya tidak lagi menemukan justifi kasinya sejak diterapkannya UU No 2 Tahun 1989 tentang Sistem Pendidikan Nasional bahwa madrasah merupakan bagian integral dari sistem pendidikan nasional, kemudian dikukuhkan oleh UU Nomor 20 Tahun 2003 tentang Sisdiknas, tetapi lebih pada pengakuan yang mantap bahwa madrasah adalah bagian dari sistem pendidikan nasional.

Madrasah adalah sekolah umum dengan ciri khas agama Islam. Perbedaan sekolah umum dan madrasah hanya pada jumlah pelajaran agama yang menjadikannya sebagai ciri khas. Ciri khas diartikan sebagai pembagian pelajaran agama menjadi beberapa sub-mata pelajaran, yakni Aqidah Akhlak, Al-Qur'an Hadits, Fiqh, dan Sejarah Kebudayaan Islam.

Sejak Orde Baru, niat untuk melakukan penataan organisasi dan peningkatan mutu pendidikan agama secara legal konstitusional memang senantiasa memperoleh perhatian besar. Hal ini secara formal tercermin dalam isi setiap Garis-garis Besar Haluan Negara (GBHN) yang dihasilkan setiap kali MPR melakukan sidang umum. Sebagai indikasi dari hal tersebut adalah masuknya masalah ini dalam ketetapan MPRS tahun 1966, 1969, dan ketetapan MPR tahun 1973, 1978, 1983, 1988, serta 1993. Ketetapan-ketetapan MPR tersebut pada prinsipnya mengamanatkan disusunnya sistem pendidikan nasional yang berjiwa pancasila dan berlandaskan Undang-undang Dasar 1945. Agar penataan, pengembangan, dan pemanta-pan pendidikan nasional dapat dilakukan, perlu disusun peraturan perundang-undangan yang menjamin pemerataan dan peningka- 
tan pendidikan bagi seluruh warga negara. Akhirnya pada tahun 1989 disepakati satu bentuk sistem pendidikan nasional yang corak dasarnya tertuang dalam UU Nomor 2 Tahun 1989 tentang Sistem Pendidikan Nasional. ${ }^{6}$

Sebuah momentum yang umumnya dianggap melegakan kalangan madrasah terjadi pada tahun 1975. Sebagai penjabaran dari Keppres No 34 Tahun 1972, pemerintah melakukan usaha peningkatan mutu madrasah melalui Surat Keputusan Bersama (SKB) Tiga Menteri yaitu Menteri Agama, Menteri Dalam Negeri, dan Men-teri P dan K, masing-masing dengan Nomor 6 Tahun 1975, nomor 037/U/1975 dan Nomor 36 Tahun 1975. Inti dari SKB tersebut adalah agar secara lintas departemental dilakukan usaha bersama untuk meningkatkan mutu pendidikan madrasah sehingga kualitas pengetahuan umum siswa madrasah bisa mencapai tingkat yang sama dengan siswa sekolah umum yang sederajat. Dengan demikian maka ijazah madrasah praktis akan diakui sama dengan ijazah sekolah umum yang setingkat atau sebaliknya.

Pengakuan persamaan ini hanya diberikan kepada madrasahmadrasah yang memenuhi syarat tertentu yaitu apabila madrasah tersebut antara lain mengajarkan pengetahuan umum sebanyak 70 $\%$ dan pengetahuan agama $30 \%$ sebagaimana tercermin dalam struktur program kurikuler yang dipakai, yaitu kurikulum Departemen Agama.

Dengan SKB 3 (tiga) menteri tersebut secara formal madrasah telah mengalami reorientasi yaitu dari orientasi tafaqquh $f i$ al-din kepada orientasi ketenagakerjaan yang tidak berbeda dengan sekolah umum biasa. Dengan kata lain, madrasah bukan lagi tempat memberikan pendidikan dan pengajaran di mana ilmu agama Islam menjadi pokok pengajarannya, melainkan sebagai "sekolah umum biasa" namun di bawah pengelolaan Departemen Agama. (Baca Kemenag).

Dengan kuantitas dan kualitas tenaga, sarana prasarana, faslitas dan dana yang jauh lebih rendah dibanding sekolah-sekolah di bawah Kemendikbud, nasib madrasah hanya hidup dan berkembang sebagai sekolah marjinal.

${ }^{6}$ Chairul Fuad Yusuf (Ed). Revitalisasi Madrasah, Puslitbang Pendidikan Agama dan Keagamaan, Badan Litbang dan Diklat Kementerian Agama, 2006, hlm 6. 
Data Kementerian Agama menyebutkan bahwa Madrasah swasta dan negeri 91,5\% adalah swasta. Ini artinya partisipasi masyarakat terhadap madrasah sangat tinggi. Bahkan bisa dikatakan bahwa madrasah sesungguhnya adalah milik masyarakat bukan pemerintah. $^{7}$

Berdasarkan uraian di atas, tulisan ini ingin mengungkap bagaimana minat masyarakat terhadap madrasah ibtidaiyah di Jawa Tengah. Sebagaimana diketahui, sentra MI berada di kabupaten Magelang dengan jumlah yang banyak, yakni 303 MI. Sentra MI di Magelang adalah di Kecamatan Grabag. Dari 27 MI yang ada di Grabag, MI Ma'arif Grabag 1 merupakan MI yang paling banyak diminati. Hal ini dibuktikan dengan banyaknya pendaftar yang ingin masuk pada madrasah tersebut.

\section{B. Rumusan Masalah}

Berdasarkan uraian di atas, peneliti merumuskan beberapa ma-salah sebagai berikut.

1. Bagaimanakah minat masyarakat untuk menyekolahkan anak mereka pada MI Ma'arif Grabag 1 Magelang?

2. Bagaimanakah pengelolaan MI Ma'arif Grabag 1 Magelang untuk memenuhi kebutuhan masyarakat menyekolahkan anak mereka?

3. Bagaimanakah model peningkatan minat masyarakat menyekolahkan anak mereka pada MI Ma'arif Grabag 1 Magelang?

\section{Teori}

Istilah minat dapat diartikan bermacam-macam oleh para pakar psikologi. Bingham (1979:21) menjelaskan bahwa ninat adalah kecenderungan untuk ikut serta aktif dalam pengalaman-pengalaman dan memelihara pengalaman tersebut. Minat (interest) dapat dikatakan lawan dari keengganan (aversion) yang dirumuskan sebagai kecenderungan untuk menjauhi terjadinya pengalaman tentang objek-objek.

\footnotetext{
${ }^{7}$ Majalah Rindang
} 
Minat (interest) dan keengganan (aversion) sifatnya dinamik. Pada satu saat mungkin minat lebih kuat daripada keengganan, disebabkan individu yang bersangkutan memusatkan perhatian kepada salah satu objek sehingga tidak ada kesempatan untuk memperhatikan objek lain. Perkembangan minat akan bergantung kepada kesempatan belajar. Dengan kata lain, minat selalu bergantung kepada lingkungan dan orang-orang dewasa yang erat pergaulannya dengan mereka. Lingkungan pada masa anak-anak mendorong kesempatan pada mereka untuk dapat mengembangkan beberapa minat tertentu, tetapi juga dapat menghilangkan beberapa kesempatan dalam pengembangan minat yang lain. Sesuai dengan perluasan lingkungan yang mencakup sekolah, tetangga, masyarakat, dan masyarakat dunia pada umumnya membuka kesempatan baru untuk tumbuhnya minat baru. Oleh karena itu, banyak minat seseorang yang hilang dan diganti oleh minat lain secepat anak memasuki masa remaja dan dewasa.

Crow and Crow (1989:302-303) berpendapat bahwa minat erat hubungannya dengan daya gerak yang mendorong seseorang untuk menghadapi atau berurusan dengan orang, benda atau bisa juga sebagai pengalaman afektif yang dipengaruhi oleh kegiatan itu sendiri. Dengan kata lain, minat dapat menjadi sebab kegiatan dan sebab partisipasi dalam kegiatan tersebut.

Daniel (1996:236) menjelaskan bahwa minat dipengaruhi oleh rasa senang dan tidak senang. Pola rasa senang dan tidak senang yang terbentuk pada setiap fase perkembangan akan relatif stabil sepanjang fase masing-masing, akan tetapi pada setiap fase berikutnya terus terjadi perubahan pola tersebut baik secara kualitas maupun kuantitas. Hal ini terjadi karena adanya perkembangan atau pembentukan objek minat pada setiap fase tersebut, sesuai dengan pertumbuhan, kematangan, dan pengalaman individu. Akibat timbulnya rasa senang dan rasa tidak senang terhadap objek-objek tertentu, pola minat mulai terbentuk terutama pada masa sekolah di SLTP.

Dilihat dari fase perkembangan, minat berkembang secara bertahap mengikuti masa perkambangan yang dilalui individu sejak masa bayi hingga dewasa. Lebih dari itu, kematangan jiwa pun tu- 
rut mempengaruhi pembentukan minat. Mula-mula minat berpusat pada diri sendiri, hal-hal yang menjadi miliknya, kemudian berpusat kepada orang lain dan objek-objek dalam lingkungannya. Thorndike dan Hagen (1961:317), mengemukakan minat sebagai keinginan untuk mencari dan berpartisipasi dalam kegiatankegiatan tertentu. Minat merupakan salah satu kepribadian, yaitu terdiri atas karakter, adjusmen, temperamen.

Pendapat tentang minat yang lebih lengkap dikemukakan oleh Chaplin (2000:1), yang merumuskan, yaitu pertama, sebagai suatu sikap yang menetap yang mengikat perhatian individu ke arah objek-objek tertentu secara selektif. Kedua, perasaan yang berarti bagi individu terhadap kegiatan, pekerjaan sambilan atau objekobjek yang dihadapi oleh setiap individu, dan ketiga, motivasi atau kesiapan individu yang mengatur atau mengendalikan perilaku dalam arah tertentu atau ke arah tujuan tertentu.

Kata minat identik dengan kata motivasi yang berasal dari kata "motif" yakni segala daya yang mendorong seseorang untuk melakukan sesuatu. Dengan minat atau motivasi dimaksud usahausaha untuk menyediakan kondisi-kondisi sehingga seseorang itu mau, dan ingin melakukannya. Manusia makhluk yang berkembang dan dipengaruhi oleh bawaan dan lingkungannya, menurut Islam teori konvergensi yang dikemukakan oleh William Stern, menjelaskan bahwa pendidikan dipengaruhi oleh dua faktor, yaitu faktor bakat atau bawaan sejak lahir dan faktor lingkungan eksternal.

Setiap anak dilahirkan membawa fitrah, baik itu bakat, potensi dan minat, sebagian besar dipengaruhi oleh lingkungan keluarga atau rumah tangga. Kedua pengaruh ini baik pengaruh lingkungan keluarga maupun bakat yang dimiliki anak, keduanya saling mendukung dan mempengaruhi. Ketika anak di sekolah hampir saja semua pengaruh pendidikan anak di sekolah bukan hanya dari segi kognitif saja akan tetapi terus berlanjut ke afektif dan psikomotorik anak, sehingga anak dapat berbuat sesuai dengan ilmu pengetahuan yang diajarkan gurunya.

Tujuan pendidikan memuat gambaran tentang nilai-nilai yang baik, luhur, pantas, benar, dan indah untuk kehidupan. Karena itu tujuan pendidikan memiliki dua fungsi yaitu memberi arah kepada 
segenap kegiatan pendidikan dan merupakan sesuatu yang ingin dicapai oleh segenap kegiatan pendidikan.Sebagai suatu komponen pendidikan, tujuan pendidikan menduduki posisi penting diantara komponen-komponen pendidikan lainnya. Dapat dikatakan bahwa seluruh komponen dari seluruh kegiatan pendidikan dilakukan semata-mata terarah kepada atau ditujukan untuk pencapaian tujuan tersebut. Dengan demikian, kegiatan-kegiatan yang tidak relevan dengan tujuan tersebut dianggap menyimpang, tidak fungsional, bahkan salah, sehingga harus dicegah terjadinya.

Di sini terlihat bahwa tujuan pendidikan itu bersifat normatif, yaitu mengandung unsur norma yang bersifat memaksa, tetapi tidak bertentangan dengan hakikat perkembangan peserta didik serta dapat diterima oleh masyarakat sebagai nilai hidup yang baik. Sehubungan dengan fungsi tujuan yang sangat penting itu, maka suatu keharusan bagi pendidik untuk memahaminya. Kekurangpahaman pendidik terhadap tujuan pendidikan dapat mengakibatkan kesalahpahaman di dalam melaksanakan pendidikan. Orang tua dan anak sebaiknya memperkokoh jalinan kerja sama yang baik dan mendukung keberhasilan anak dalam membentuk manusia seutuhnya di masa mendatang.

Minat orang tua memasukkan anaknya ke lembaga pendidikan agama berfungsi memelihara keluarganya terutama anaknya semoga terhindar dari segala macam ancaman baik di dunia mapun diakhirat kelak. Setiap orang tua diperintahkan untuk memelihara keluarganya dari ancaman api neraka.

Pendapat lain dikemukakan bahwa minat merupakan kecenderungan psikologis yang menyenangi sesuatu objek dan belum sampai melakukan kegiatan. Minat merupakan potensi psikologi yang dapat dimanfaatkan untuk menjadi motivasi (Djamarah 2009:155).

Pada bagian lain, minat menurut Djamarah adalah kecenderungan yang menetap untuk memperhatikan dan mengundang bebera-pa aktivitas. Seseorang yang berminat terhadap suatu aktivitas akan memperhatikan aktivitas itu secara konsisten dalam rasa senang. Dengan kata lain, minat adalah suatu rasa lebih suka dan rasa ketertarikan pada suatu hal atau aktivitas tanpa ada yang menyuruh. Minat pada dasarnya adalah penerimaan akan suatu hubungan an- 
tara diri sendiri dengan sesuatu di luar diri. Semakin kuat atau dekat hubungan tersebut, semakin besar minat (Djamarah 2009:132).

Suatu anggapan yang keliru adalah mengatakan bahwa minat dibawa sejak lahir. Minat adalah perasaan yang didapat karena berhubungan dengan sesuatu. Minat terhadap sesuatu itu dipelajari dan dapat mempengaruhi belajar selanjutnya serta mempengaruhi penerimaan minat baru. Jadi minat terhadap sesuatu merupakan hasil belajar dan cenderung mendukung aktivitas belajar berikutnya.

Minat ialah sesuatu pemusatan perhatian yang tidak disengaja yang terlahir dengan penuh kemauannya dan yang tergantung dari bakat dan lingkungannya (Sujanto 2008:92). Minat (interest) berarti kecenderungan dan kegairahan yang tinggi atau keinginan yang besar terhadap sesuatu (Syah, 2004: 136). Menurut Ruber (1988) minat tidak termasuk istilah populer dalam psikologi karena ketergantungannya yang banyak pada faktor-faktor internal lainnya seperti pemusatan perhatian, keingintahuan, motivasi, dan kebutuhan (Psikologi Pendidikan dengan pendekatan baru).

WS Winkel memberikan defi nisi minat adalah kecenderungan yang agak menetap dalam subjek merasa tertarik pada bidang/hal tertentu dan merasa senang berkecimpung dalam bidang itu (Winkel 1983:30). Perasaan senang akan menimbulkan minat pula, yang diperkuat lagi oleh sikap yang positif, yang mana di antara hal-hal itu timbul lebih dahulu, sukar ditentukan secara pasti. Pada umumnya berlaku urutan psikologi sebagai berikut: perasaan senangsikap positif-minat.

Terdapat hubungan yang erat antara bermotivasi instrinsikberminat-berperasaan senang. Sikap yang positif terhadap belajar di madrasah pasti memiliki peranan besar dalam hubungan ketiga hal itu, meskipun bukan untuk menunjukkan fungsi dari sikap itu secara pasti (semacam lem yang menyatukan) (Winkel 1985:31).

Minat masyarakat terhadap madrasah merupakan kecenderungan orang tua wali dalam memilih pendidikan untuk anaknya. Wujud dari implementasi minat adalah menyekolahkan anak mereka ke madrasah sebagai pilihan untuk pendidikan anak. 


\section{Metode Penelitian}

Penelitian ini menggunakan Research and Development yaitu metode penelitian yang digunakan untuk menghasilkan produk tertentu, dan menguji keefektifan produk tersebut. (Sugiyono, 407). Meskipun demikian, dalam penelitian ini hanya sampai pada menghasilkan produk tertentu, yakni model peningkatan minat masyarakat untuk menyekolahkan anaknya di madrasah.

Secara empirik langkah penelitian dan pengembangan dapat dikemas menjadi tiga tahap utama, yakni: tahap studi pendahuluan, tahap pengembangan, dan tahap validasi model. Penelitian ini berhenti pada tahap pengembangan model, yaitu model peningkatan minat masyarakat terhadap Madrasah Ibtidaiah Ma'arif Grabag 1 Magelang.

\section{E. Hasil Penelitian}

\section{Sekilas MI Ma'arif Grabag 1}

MI Ma'arif Grabag 01 berada di Jl Candi Umbul Grabag Telp (0293) 3148107 Kecamatan Grabag kabupaten Magelang Jawa Tengah. Secara tertulis, visi madrasah tersebut adalah terwujudnya madrasah yang melahirkan generasi Qur'ani, kreatif, inovatif, terampil, dan mandiri. Sedangkan misinya (1) menciptakan lingkungan belajar yang kreatif, menantang, dan terintegrasi dalam rangka mewujudkan visi, (2) memberdayakan seluruh potensi peserta didik dan ragam kecerdasan agar berprestasi maksimal secara intelektual, emosional, dan spiritual.

Tujuan Madrasah Ibtidaiyah Ma'arif Grabag 1 adalah memberikan bekal kemampuan dasar "baca, tulis, dan menghitung" pengetahuan dan keterampilan dasar yang bermanfaat bagi siswa, memberikan kemampuan dasar tentang pengetahuan agama Islam dan pengalaman sesuai dengan tingkat perkembangan anak untuk mengikuti jenjang yang lebih dengan sistem pendekatan integral learning serta KBM diselenggarakan dengan model full daya schoool.

Nama-nama guru di MI Ma'arif Grabag 1 adalah sebagai berikut: 


\begin{tabular}{|c|l|c|}
\hline No & Nama & Pendidikan \\
\hline 1 & Subandi, S.PdI M.Pd & S-2 \\
\hline 2 & Darul Hikmah, S.Ag & S-1 \\
\hline 3 & Fatkhul Mujib, S.pdI & S-1 \\
\hline 4 & Farida Himawati, S.pdI & S-1 \\
\hline 5 & Iswanto, S.pdI & S-1 \\
\hline 6 & Muhammad Wildan, S.HI & S-1 \\
\hline 7 & Prastiwi Bhakti Nurani, SS & S-1 \\
\hline 8 & Puji Hartono, S.pdI & S-1 \\
\hline 9 & Uswatun Hasanah, S.pdI & PGA \\
\hline 10 & Muh Rosdik & MAN \\
\hline 11 & Taufik Arifudin & \\
\hline
\end{tabular}

Pada tahun 2011/2012 jumlah rombongan belajar MI Ma'arif Grabag 1 adalah sebagai berikut

\begin{tabular}{|c|c|c|c|c|c|c|}
\hline Kls 1 & Kls 2 & Kls 3 & Kls 4 & Kls 5 & Kls 6 & Jml \\
\hline 2 & 2 & 2 & 2 & 1 & 1 & 10 \\
\hline
\end{tabular}

Sedangkan jumlah anak didik adalah sebagai berikut

\begin{tabular}{|c|c|c|c|}
\hline Kelas & Laki-laki & Perempuan & Jumlah \\
\hline 1 & 29 & 29 & 58 \\
\hline 2 & 22 & 33 & 55 \\
\hline 3 & 24 & 22 & 46 \\
\hline 4 & 20 & 23 & 43 \\
\hline 5 & 16 & 19 & 35 \\
\hline 6 & 16 & 8 & 24 \\
\hline Total & 127 & 134 & 261 \\
\hline
\end{tabular}

Dilihat dari pekerjaan orang tua adalah petani, pengusaha atau pedagang, pensiunan, sopir, PNS, karyawan swasta, pekerja pabrik, dan lainnya. Dari 261 siswa tersebut dikategorikan berdasarkan tingkat ekonomi orang tua. 


\begin{tabular}{|c|l|c|}
\hline No & Kategori & Jumlah \\
\hline 1 & Tidak Mampu & 55 orang \\
\hline 2 & Kurang Mampu & 151 orang \\
\hline 3 & Mampu & 55 orang \\
\hline \multicolumn{2}{|c|}{ Jumlah } & 261 orang \\
\hline
\end{tabular}

Meskipun MI Ma'arif diminati masyarakat (peserta didiknya banyak), namun dilihat dari akreditasinya masih dalam kategori B (95). Artinya, ada beberapa elemen dalam penilaian akreditasi yang belum terpenuhi oleh MI Ma'arif Grabag 1 Magelang.

\section{Minat Masyarkaat terhadap MI Ma'arif Grabag 1}

Minat masyarakat untuk menyekolahkan anak mereka pada MI Ma'arif Grabag 1 Magelang tergolong tinggi. Hal ini ditunjukkan dengan banyaknya orang tua wali yang ikut mendaftarkan puteraputerinya ke madrasah tersebut. Pada tahun 2012 MI Ma'arif Grabag 1 menerima pendaftaran murid baru dengan hanya membuka waktu pendaftaran 6 hari (9 April - 14 April 2012). Itu pun dilakukan dengan promosi yang minim hanya sebuah spanduk.

Menurut kepala MI, Subandi, meskipun hanya 1 minggu jumlah pendaftarnya membludak. Banyak orang tua yang menghubungi saya supaya diterima, tetapi saya sampaikan silahkan daftar aja ke panitia penerimaan siswa baru di madrasah. Seandainya madrasah ini memiliki ruang kelas yang cukup, tentu bisa menerima siswa lebih banyak lagi tetapi karena kapasitas ruangan terbatas, tentu tidak bisa memaksakan.

Minat yang tinggi dari masyarakat untuk menyekolahkan anaknya di sini tentu merupakan buah dari usaha yang telah dilakukan madrasah ini bertahun-tahun. Usaha tersebut membuahkan hasil dengan banyaknya siswa dan bentuk partisipasi yang tinggi dari masyarakat.

Minat masyarakat yang tinggi terhadap madrasah dipengaruhi oleh banyak faktor misalnya pada bentuk layanan pendidikan yang diberikan oleh madrasah. Delapan (8) standar nasional pendidikan menjadi perhatian penting yaitu standar isi, standar proses, standar 
kompetensi lulusan, standar sarana dan prasarana, standar pembiayaan, dan standar penilaian pendidikan.

Banyaknya masyarakat yang mendaftarkan anaknya ke MI Ma'arif Grabag 1 karena banyak faktor. Baik yang ilmiah maupun alasan taktis. Alasan ilmiah terkait dengan pengelolaan MI Ma'arif Grabag 1 yang unggul. Beberapa program unggulan MI Ma'arif Grabag 1 adalah laboratorium komputer, audio visual, hafalan juz 30, jarimatika, kaligrafi, perpustakaan, outbond, bahasa Arab, bahasa Inggris, dan hot spot area.

Selain faktor-faktor di atas banyak wali murid siswa MI Grabag 1 adalah pedagang pasar sehingga alasan mereka memasukkan ke madrasah diantaranya karena waktu pulang di MI tersebut lebih lama. Beberapa wali murid menyampaikan bahwa mereka menyekolahkan anak di situ karena kebetulan waktu pulang siswa-siswinya adalah pukul 13.30 WIB sehingga cocok dengan waktu pulang kerja. Banyak orang tua wali yang bekerja di pasar, dan menjadi guru yang kebetulan waktu pulangnya bersamaan dengan waktu pulang anak sehingga bisa antarjemput.

\section{Pengelolaan MI Ma'arif Grabag 1}

Pengelolaan MI Ma'arif Grabag 1 dapat diperoleh melalui instrumen angket yang diberikan kepada guru terhadap beberapa dimensi penelitian yaitu standar isi, standar proses, standar kompetensi lulusan, standar pendidik dan tenaga kependidikan, standar sarana dan prasarana, standar pengelolaan, standar pembiayaan, dan standar penilaian.

Pada standar isi apakah KTSP yang dikembangkan memuat mata pelajaran agama dan akhlak mulia, mengakomodasi pelajaran kewarganegaraan dan kepribadian, mengakomodasi mata pelaja-ran iptek, mapel estetika, mapel jasmani, olah raga, dan kesehatan, mengakomodasi pendidikan kecakapan hidup, penddidikan berbasis keunggulan lokal, serta ketersediaan kalender akademik.

Standar proses meliputi terselenggaranya proses pembelajaran secara interaktif, perencanaan proses pembelajaran yang meliputi silabus dan RPP, memperhatikan jumlah maksimal peserta didik dalam kelas, penilaian menggunakan, pemberian kesempatan peserta 
didik untuk mengikuti berbagai lomba, menjalin kerja sama dengan berbagai instansi, publikasi madrasah, penyelenggaraan pertemuan dengan wali murid, program unggulan madrasah, serta kegiatan ekstrakurikuler yang dapat menampung kebutuhan pengembangan potensi peserta didik.

Standar kompetensi lulusan (SKL) digunakan sebagai pedoman penilaian dalam penentuan kelulusan peserta didik dan menggunakan SKL untuk meletakkan dasar kecerdasan, pengetahuan, kepribadian, ahklak mulia, serta keterampilan untuk hidup mandiri dan mengikuti pendidikan lebih lanjut.

Standar pendidik dan tenaga kependidikan meliputi minimal berijazah sarjana, penempatan tugas mengajar sesuai dengan keahlian, pemberian kesempatan guru untuk mengikuti pelatihan-pelatihan, pemberian kesempatan guru untuk mengikuti berbagai lomba akademis, pemberian kesempatan MGMP, program-program pengembangan profesi, kondusifi tas iklim akademis madrasah, memiliki tenaga kependidikan sekurang-kurangnya terdiri atas kepala madrasah, tenaga administrasi, tenaga perpustakaan, tenaga laboratorium, dan tenaga kebersihan.

Standar sarana dan prasarana meliputi ketersediaan peralatan pendidikan, media pendidikan, buku dan sumber belajar lainnya, lahan, ruang kelas, ruang kepala, guru, tata usaha, perpustakaan, laboratorium, rasio jumlah peserta didik, serta kualitas perawatan sarana dan prasarana pendidikan.

Standar pengelolaan meliputi madrasah yang menerapkan menajemen berbasis madrasah (MBS), keputusan bidang akademik dilakukan oleh rapat dewan akademik, keputusan di bidang nonakademik dilakukan oleh komite madrasah, rapat dewan pendidik dan komite madrasah dilaksanakan atas dasar prinsip musyawarah mufakat untuk peningkatan mutu, madrasah memiliki KTSP, pedoman penyusunan kalender akademik, struktur organisasi madrasah, pembagian tugas di antara pendidik dan tenaga kependidikan, penyusunan peraturan akademik, memiliki tata tertib, kode etik, biaya operasional madrasah, efektivitas, efisiensi dan akuntabilitas madrasah, serta adanya supervisi manajerial dan akademik.

Standar pembiayaan termasuk ketersediaan biaya operasional 
pendidikan: gaji pendidik dan tenaga keepndidikan, peralatan pendidikan habis pakai, air telepon, serta ketersediaan biaya investasi pendidikan, biaya personal peserta didik, pemberian beasiswa, akuntabilitas pendanaan madrasah kepada warga madrasah dan stakeholder.

Standar penilaian pendidikan meliputi penilaian dan pelaporan hasil belajar secara berkesinambungan ulangan harian, ulangan tengah semester, ulangan akhir semester, dan ulangan kenaikan kelas, penilaian dan pelaporan hasil belajar oleh satuan pendidikan, dan penilaian dan pelaporan hasil belajar oleh pemerintah.

Pengelolaan MI Ma'arif Grabag 1 Magelang meliputi program unggulan dan pembiasaan yang berlaku di MI Ma'arif Grabag 1. Program unggulan yang ada di MI Ma'arif Grabag 1 meliputi: laboratorium komputer, audio visual, hafalan juz 30, jarimatika, kaligrafi, perpustakaan, outbond, bahasa Arab, bahasa Inggris, hot spot area. Pembiasaan yang berlaku di MI ini adalah bersamalam setiap pagi di pintu gerbang, ketika masuk kelas, sholat dhuha, sholat dzuhur, dan ketika pulang.

\section{Model Peningkatan Minat Masyarakat terhadap MI Ma'arif Grabag 1}

Dalam suatu Focus Group Discussion (FGD) dengan stakeholder madrasah ada beberapa hal yang menjadikan madrasah diminati masyarakat. Dalam bahasa mudah, madrasah harus mempunyai idealisme. Tentu harapan tetap ada agar madrasah menjadi sekolah terpadu, plus, dan unggulan. Beberapa hal menjadi perhatian agar bisa mendongkrak minat masyarakat terhadap madrasah adalah sebagai berikut.

1. Memiliki program unggulan

Program unggulan mestinya dilakukan di madrasah yang dapat mendongkrak nilai jual madrasah di antaranya adalah: Tabfidz al Qur'an, kemampuan bahasa Arab/Inggris, mampu memimpin ibadah sesuai kebutuhan masyarakat seperti tahlilan, memiliki program pembiasaan untuk memembentuk akhlaqul karimah dan ibadah sunnah, full day school, serta penguasaan IT.

2. Berakhlaq mulia, memiliki ketaatan beragama 
Persoalan akhlak dalam pendidikan madrasah merupakan sesuatu yang sentral. Bahkan, kehadiran Nabi Muhammad ke muka bumi pada hakikatnya adalah untuk memperbaiki akhlak manusia. Sehingga, persoalan akhlak menjadi sentral dalam kegiatan di madrasah. Tidak hanya terhadap siswa, termasuk juga pihak kepala dan guru yang memberikan teladan akhlak yang baik bagi masyarakat di lingkungan sekitar.

Bahkan, beberapa MI justru menjadikan jualan akhlak ini lebih penting daripada prestasi UN sekalipun. Pembiasanpembiasaan yang di madrasah kaitannya dengan pembentukan akhlak menjadi sangat sentral agar madrasah diminati masyarakat; berjabat tangan dengan guru, mengingatkan sholat malam (tahajud call), dan pelibatan siswa untuk membantu kegiatan di masyarakat.

Aktivitas siswa madrasah baik untuk kegiatan ibadah (sholat berjamaah) maupun kegiatan sosial ada baiknya membaur dengan masyarakat sekitar. Dengan demikian, akan terjalin komunikasi intensif antara pihak madrasah dengan masyarakat.

3. Banyak lulusan siswa/outcome diterima di sekolah favorit, pesantren

Out put siswa dalam akademik maupun akhlak adalah pent-ing. Tetapi outcome siswa dalam arti banyak yang diterima di pendidikan favorit (madrasah, sekolah, ataupun pesantren) juga tidak kalah penting. Sebagai bentuk publikasi yang mudah dilihat adalah diterima lulusan madrasah di berbagai lembaga yang bonafide.

4. Mempunyai prestasi non akademik seperti olah raga, lomba pidato, dsb

Tidak kalah penting juga adalah prestasi siswa di bidang non akademik. Banyak kegiatan lomba-lomba yang harus diikuti oleh pihak madrasah agar eksistensinya diakui. Apapun lombanya, idealnya pihak madrasah selalu mengikutkan siswa-siswinya. Jangan ada pikiran pihak madrasah rugi jika mengikutkan perlombaaan untuk anak didiknya. Apalagi kalau hanya alasan takut kalah.

5. Nilai prestasi akademik / UN baik

Prestasi adalah mantra agar sesuatu bernilai. Apapun profesi dan aktivitas kita memang prestasi adalah kata kunci. Dalam dunia pendidikan prestasi tentu menyangkut tiga hal; prestasi ma- 
drasah, prestasi guru, dan prestasi siswa. Madrasah ideal adalah madrasah yang berprestasi di berbagai bidang. Demikian juga, gurunya harus berprestasi serta memiliki komitmen yang tinggi untuk memajukan madrasah. Namun, untuk kepentingan publikasi prestasi siswa dalam UN adalah yang paling mudah dilihat oleh masyarakat.

Oleh karena itu, pencapaian UN adalah mutlak agar madrasah tidak dilihat sebelah mata oleh masyarakat. Pencapaian UN merupakan suatu keharusan. Lebih penting juga adalah publikasi yang madrasah terhadap prestasi UN yang telah diraih ma-drasah.

Konon, beberapa UPTD Dinas Pendidikan, ketika madrasah yang mendapat ranking prestasi UN biasanya tidak publikasikan. Tetapi jika pihak sekolah yang mendapatkan ranking prestasi UN, selain dipublikasikan juga mendapatkan piala bergilir. Bentuk pendzoliman dinas terhadap madrasah tidak perlu disikapi negatif. Toh, pihak madrasah bisa membuat publikasi sendiri tentang prestasi UN tersebut. Meskipun tentu hal itu, tentu sangat disayangkan.

\section{F. Simpulan Dan Rekomendasi}

\section{Simpulan}

Berdasarkan uraian di atas dapat disimpulan sebagai berikut:

1. Minat masyarakat untuk menyekolahkan anak mereka pada MI Ma'arif Grabag 1 Magelang tergolong tinggi. Hal ini ditunjuk-kan dengan banyaknya orang tua wali yang ikut mendaftarkan puteraputerinya ke madrasah tersebut. Kapasitas atau tampung MI Ma'arif terbatas namun pendaftarnya dari tahun ke tahun membludak. Meskipun belum dapat dipastikan bahwa banyaknya orang tua yang menyekolahkan anak pada madrasah tersebut murni semata-mata karena program dan pengelolaan madrasah yang unggul. Sebab, beberapa wali murid menyampaikan bahwa mereka menyekolahkan anak di situ karena kebetulan waktu pulang siswa-siswinya adalah pukul 13.30 WIB sehing- 
ga cocok dengan waktu pulang kerja. Mafhum, bahwa banyak orang tua wali yang bekerja di pasar dan menjadi guru yang kebetulan waktu pulangnya bersamaan dengan waktu pulang anak sehingga bisa antarjemput.

2. Pengelolaan MI Ma'arif Grabag 1 Magelang meliputi program unggulan dan pembiasaan yang berlaku di MI Ma'arif Grabag 1. Program unggulan yang ada di MI Ma'arif Grabag 1 meliputi: laboratorium komputer, audio visual, hafalan juz 30, jarimatika, kaligrafi, perpustakaan, outbond, bahasa Arab, bahasa Inggris, hot spot area. Pembiasaan yang berlaku di MI ini adalah bersalaman setiap pagi di pintu gerbang, ketika masuk kelas, sholat dhuha, sholat dzuhur, dan ketika pulang.

3. Model peningkatan minat masyarakat menyekolahkan anak mereka pada MI Ma'arif Grabag 1 Magelang adalah dengan memiliki program-program unggulan, membiasakan akhlak mulia, alumni banyak diterima di lembaga favourit, memiliki prestasi non akademik yang bagus, serta memiliki prestasi akademik yang baik.

\section{Saran}

Berdasarkan temuan hasil penelitian di atas ada beberapa hal yang perlu disarankan sebagai berikut.

1. MI Ma'arif Grabag 1 perlu lebih meningkatan mutu pendidikan tidak hanya semata-mata pada aspek kuantitas jumlah peserta didik tetapi juga peningkatan kualitas, misalnya dalam hasil Ujian Nasional (UN). Demikian pula akreditasi madrasah perlu ditingkatkan minimal mencapai nilai 96 (A).

2. Madrasah-madrasah yang lain perlu meniru langkah-langkah yang telah dilakukan madrasah ini dalam meningkatkan minat masyarakat untuk menyekolahkan anaknya ke madrasah, utamanya pada aspek program unggulan yang dikembangkan di madrasah tersebut. 
Aji Sofanudin

\section{DAFTAR PUSTAKA}

Aly, Abdullah. 2011. Pendidikan Islam Multikultural di Pesantren; Telaah terhadap Kurikulum Pondok Pesantren Modern Islam Assalam Sura-karta. Yogyakarta: Pustaka Pelajar

Achmad, Zainal. 2001. Analisis Tingkeat Partisipasi Pendidikan Siswa Madrasah. www.kemenag.go.id

Bingham, Walter V. 1949. Aptitudes and Aptitutes Testing. New York: Harper and Bother

Chaplin, J.P. 1968. Dictionary of Psychology. New York: Dell Publishing Co.

Crow, L.D. dan A. Crow. 1958. Human Development and Learning. New York: American Book Co.

Daniel, Henry B. 1966. Guidance in Modern School. New York: Holt Rinehart and Winston.

Depdikbud. 1994. Pembangunan Pendidikan dan Kebudayaan Menjelang Era Tinggal Landas. Jakarta: Depdikbud.

Gall, Meredith D. Joyce P Gall dan Walter R Borg. 2003. Educational Research an Interoduction ( $7^{\text {th }}$ ed). New York: Pearson Education Inc. 
Idahram, Syaikh. 2011. Mereka Memalsukan Kitab-kitab Karya Ulama Klasik. Yogyakarta: Pustaka Pesantren

Notonagoro. 1973. Filsafat Pendidikan Nasional Pancasila. Yogyakarta: IKIP Yogyakarta.

Peraturan Pemerintah RI Nomor 19 Tahun 2005 tentang Standar Nasional Pendidikan.

Saridjo, Marwan. 1996. Bunga Rampai Pendidikan Agama Islam. Jakarta: CV Amissco

Slameto. 1995. Belajar dan Faktor-faktor yang Mempengarubi. Jakarta: Rineka Cipta.

Sudibyo, Bambang. 2008. Depdiknas Optimis Target Wajib Belajar 9 Tabun Tuntas Tabun ini. Mendiknas online.

Sugiyono. 2010. Metode Penelitian Pendidikan, Pendekatan Kuantitatif, Kualitatif, dan R\&D. Bandung: CV Alfabeta

Sulistiyo T. 2003. Wawasan Pendidikan. Direktorat Pendidikan Lanjutan Pertama. Direktorat Jenderal Pendidikan Dasar dan Menengah, Departemen Pendidikan Nasional

Suprayogo, Imam. 2007. Quo Vadis Madrasab; Gagasan, Aksi, dan Pembangunan Madrasah

Syah, Muhibbin. 2004. Psikologi Pendidikan dengan Pendekatan Baru. Bandung: PT Remaja Rosdakarya

Syahza, Almasdi. 2004. Masterplan Pendidikan Kabupaten Rokan Hilir. Kerjasama Pemda Kabupaten Rokan Hilir dengan FKIP

Syukur, Fatah. 2011. Manajemen Pendidikan Berbasis pada Madrasah. Semarang: Pustaka Rizki Putra 
Aji Sofanudin

Unri. Bagansiapiapi.

2006a. Potret Pendidikan Propinsi Riau. BPPDM FKIP Unri, Pekanbaru.

2006b. Paradigma Baru Pembangunan Pendidikan Daerah Riau. Pekanbaru: BPPDM FKIP Unri.

--------. 2007. Ekonomi Sumber Daya Manusia dan Alam. Pekanbaru: Cendikia Insani.

2008. Ekonomi Pembangunan. Pekanbaru: Cendekia Insani.

Syukur, Fatah. 2011. Manajemen Pendidikan Berbasis pada Pesantren. Semarang: PT Pustaka Rizki Putra.

Taruna, Mulyani Mudis. 2009. Pelaksanaan KTSP pada Madrasah Tsanawiyah Negeri di Kalimantan Selatan, Jawa Timur, dan DIY. Semarang: Balai Litbang Agama Semarang

Tim Komisi Pendidikan. Model Pemerataan dan Perluasan Akses Pendidikan Bermutu Berbasis Potensi Daerah dan Standar Nasional Pendi-dikan. Direktorat Penelitian dan Pengabdian kepada Masyara-kat Direktorat Jenderal Pendidikan Tinggi.

Undang-undang RI Nomor 20 Tahun 2003 tentang Sistem Pendidikan Nasional.

Usman, Moh. Uzer dan Lilis Setiawati. 2000. Upaya Optimalisasi Kegiatan Belajar Mengajar. Bandung: PT Remaja Rosdakarya.

Winkel, WS. 1983. Psikologi Pendidikan dan Evaluasi Belajar. Jakarta: PT Gramedia.

Yusuf, Choirul Fuad, dkk. 2006. Revitalisasi Madrasah. Puslitbang Pendidikan Agama dan Keagamaan Jakarta 
, Potret Madrasab di Media Massa. Puslitbang Pendidikan Agama dan Keagamaan Jakarta

-, Isu-isu Sekitar Madrasah. Puslitbang Pendidikan Agama dan Keagamaan Jakarta

-,Inovasi Pendidikan Agama.Puslitbang Pendidikan Agama dan Keagamaan Jakarta. 